\title{
Research on Nigella sativa: A Scientometric Assessment of Gllobal Publications' Output during 1989-2018
}

\begin{abstract}
B. M. Gupta, K. K. Mueen Ahmed ${ }^{1}$
Formerly with CSIR-National Institute of Science, Technology and Development Studies, New Delhi, ${ }^{1}$ Phcog.Net, Bengaluru, Karnataka,
\end{abstract}

India

\section{Abstract}

Aim: The present study aimed to perform scientometric assessment of global publications' output of research on Nigella sativa during 1989-2018.

Materials and Methods: The present study examined 3718 global publications on N. sativa, as indexed and covered in international Scopus database during 1989-2018, with a view to understand their growth rate, global publication share, citation impact, international collaborative papers' share, distribution of publications by broad subjects, productivity and citation profile of top organizations and authors, preferred media of communication, and bibliographic characteristics of highly cited papers. The global publications on $N$. sativa registered $20.87 \%$ annual average growth rate, and its citation impact averaged to 19.08 citations per paper.

Results: The global share of top ten countries on N. sativa ranged from $3.15 \%$ to $23.91 \%$, with the largest share $(23.91 \%)$ from India, followed by Iran $(9.58 \%)$, Egypt $(9.06 \%)$, the USA $(7.15 \%)$, etc., Nearly $81.31 \%$ and $75.74 \%$ of the global publication and citation share came from the top 10 countries during 1989-2018. The cumulative global share of the top 10 countries increased from $70.56 \%$ to $82.58 \%$ from $1989-2003$ to 2004-2018. Five countries registered relative citation index above the world average of 0.93 as follows: Germany (1.86), the USA (1.54), Turkey (1.33), Saudi Arabia (1.16), and Egypt (0.94) during 1989-2018. Pharmacology, toxicology, and pharmaceutics contributed the largest global publication share of 33.97\%, followed by agricultural and biological sciences $(32.92 \%)$; medicine $(30.10 \%)$; biochemistry, genetics, and molecular biology $(24.74 \%)$; chemistry $(12.40 \%)$; immunology and microbiology $(6.97 \%)$; environmental science (5.38\%); and veterinary science (3.60\%) during 1989-2018. A total of 432 organizations and 642 authors participated in the global research on $N$. sativa during 1989-2018, of which the top 15 most productive research organizations and the authors collectively contributed $23.45 \%$ and $6.64 \%$ of the global publication share and $21.82 \%$ and $8.04 \%$ of the global citation share, respectively, during $1989-2018$. Among 3655 journal papers (in 364 journals) in global $N$. sativa research, the top 15 most productive journals together contributed $13.54 \%$ of global share of the total journal publication output during 1989-2018.

Conclusion: One hundred and twenty-six publications were found to be highly cited, as they registered citations from 100 to 2971 during 1989-2018 and they together received 23,426 citations, averaging to 185.92 citations per paper.

Keywords: Bibliometrics, global research output, medicinal plant, Nigella sativa, scientometrics

Address for correspondence: Dr. K. K. Mueen Ahmed, Phcog.Net, No. 9, Wheeler Road Extn, St. Thomas Town, Bengaluru, India.

E-mail: mueen.ahmed@gmail.com

\begin{tabular}{|l|l|}
\hline \multicolumn{2}{|c|}{ Access this article online } \\
\hline Quick Response Code: & Website: \\
\hline & www.jpionline.org \\
\cline { 2 - 3 } & \\
\hline & DOI: \\
\hline
\end{tabular}

This is an open access journal, and articles are distributed under the terms of the Creative Commons Attribution-NonCommercial-ShareAlike 4.0 License, which allows others to remix, tweak, and build upon the work non-commercially, as long as appropriate credit is given and the new creations are licensed under the identical terms.

For reprints contact: reprints@medknow.com

How to cite this article: Gupta BM, Mueen Ahmed KK. Research on Nigella sativa: A scientometric assessment of global publications' output during 1989-2018. Int J Pharma Investig 2018;8:173-81. 


\section{INTRODUCTION}

Medicinal plants have been a major source of nutrition, health-care, and therapeutic agents since ancient times to cure human diseases. However, scientific research interest in medicinal plants received a thrust during the mid-1970s when the World Health Organization (WHO) proposed the incorporation of traditional medicine into the health-care system. In 1978, the World Health Assembly called for a comprehensive approach to the medicinal plants that included the designation of research and training centers for the study and use of medicinal plants. According to WHO, about $80 \%$ of the population in the world relies on traditional medicine for the treatment of various diseases. Nowadays, there is a manifold increase in the medicinal plant-based industries due to interest in the use of medicinal plants throughout the world, which is growing at the rate of 7\%-15\% annually. Nigella sativa (also known as black pepper and black cuminis) is a widely used medicinal plant throughout the world. It is very popular in various traditional systems of medicine such as Unani and Tibb, Ayurveda, and Siddha. Its seeds and oil have a long history of folklore usage in various systems of medicines and food. The seeds of N. sativa have been widely used in the treatment of different diseases and ailments. In Islamic literature, it is considered one of the greatest forms of healing medicine available. The Islamic prophet Muhammad once stated that the black seed can heal every disease except death. Avicenna, most famous for his volumes called "The Canon of Medicine," refers to Nigella as the seed that stimulates the body's energy and helps recovery from fatigue and dispiritedness. It is also included in the list of natural drugs of "Tibb-e-Nabawi" or "Medicine of Prophet (Mummad)." "[1]

N. sativa has been widely used as antihypertensive, liver tonics, diuretics, digestive, antidiarrheal, appetite stimulant, analgesics, antibacterial, and in skin disorders. Extensive studies on $N$. sativa have been carried out by various researchers, and a wide spectrum of its pharmacological actions have been explored which may include antidiabetic, anticancer, immunomodulator, analgesic, antimicrobial, anti-inflammatory, spasmolytic, bronchodilator, hepatoprotective, renal protective, gastroprotective, and antioxidant properties. Black cumin (N. sativa L.) seeds contain both fixed and essential oils, proteins, alkaloids, and saponin. Much of the biological activity of the seeds has been shown to be due to thymoquinone (TQ), the major component of the essential oil, but which is also present in the fixed oil. The pharmacological actions of the crude extracts of the seeds (and some of its active constituents, for example, volatile oil and TQ, that have been reported include protection against nephrotoxicity and hepatotoxicity induced by either disease or chemicals. ${ }^{[2,3]}$

The published findings provide clear evidence that both the oil and its active ingredients, in particular TQ, possess reproducible antioxidant effects through enhancing the oxidant scavenger system, which as a consequence lead to antitoxic effects induced by several insults. The oil and TQ have also shown potent anti-inflammatory effects on several inflammation-based models including experimental encephalomyelitis, colitis, peritonitis, edema, and arthritis through suppression of the inflammatory mediators' prostaglandins and leukotriens. The oil and certain active ingredients have shown beneficial immunomodulatory properties, augmenting the T-cell and natural killer cell-mediated immune responses. Most importantly, both the oil and its active ingredients have proven to express antimicrobial and antitumor properties toward different microbes and cancers. Coupling these beneficial effects with its use in folk medicine, N. sativa seed is a promising source for active ingredients that would be with potential therapeutic modalities in different clinical settings. ${ }^{[4]}$

Literature review

Only one bibliometric study made a bibliometric assessment of $N$. sativa research in the past. Anwar ${ }^{[5]}$ carried out a bibliometric analysis of the literature on N. sativa (Habbat al-barakah or black seed). The purpose was to study the periodic growth of literature, author patterns, topical focus, and geographic origin of literature on the subject. Twenty related databases and several online catalogues of libraries were searched to identify a final list of 530 citations. This data set was analyzed using various bibliographic characteristics. However, similar bibliometric studies have been published on other individual medicinal plants such as Aloe vera, ${ }^{[6]}$ Azadirachta indica, ${ }^{[7]}$ Curcuma longa, ${ }^{[8]}$ Glycyrrbiza glabre, ${ }^{[9]}$ Ocimum santum, ${ }^{[10]}$ Pheonix dactylifera ${ }^{[1]}$ Tinospora cordifolia, ${ }^{[12]}$ and Phyllanthis emblica. ${ }^{[13]}$

\section{MATERIALS AND METHODS}

\section{Objectives}

The literature on N. sativa is widely scattered and difficult to identify due to the the interdisciplinary nature of research on this plant. There is a need to identify and analyze this literature in order to study its various aspects. This can be done through bibliometric analysis of the literature. The present study examined the quantitative and qualitative aspects of global $N$. sativa research output, in terms of select bibliometric indicators during 30 years (1989-2018), based on publications indexed in Scopus database. Its objectives are (i) to study the growth and distribution 
of global literature on N. sativa; (ii) to examine the scientometric profile and characteristics of the ten most productive countries, 25 most productive organizations, and 25 most productive authors; (iii) to study the distribution of publication output by broad subject areas and identification of significant keywords; and (iv) to identify the medium of communication and the bibliographic characteristics of highly cited publications on $N$. sativa.

\section{Methodology}

The world's top ten most productive countries' global publications on $N$. sativa were sourced from Scopus international database (http:/ / www.scopus.com), using two keywords "Nigella sativa" or "Black Pepper" for the years 1989-2018. The Key world tag and Title of papers (as shown in search string below) tags was searched for the two keywords restricting the hit to the period 1989-2018 in "date range" tag. The statement becomes the main search string. The main search string was further restricted to individual ten countries in "country" tag one by one for obtaining publication data of these countries. On further restricting global search string by "subject area tag," "country tag," "source title tag," "journal title name," and "affiliation tag," statistics on the distribution of publications by subject, collaborating countries, author wise, organization wise, and journal wise, etc., were obtained. Citation data were obtained from the date of publication till December 30, 2018. Select bibliometric indicators have been used to study the performance of global N. sativa research.

(KEY ["Nigella sativa" or "Black Pepper"] OR TITLE ["Nigella sativa" or "Black Pepper"]) AND PUBYEAR > 1988 AND PUBYEAR < 2019.

\section{Analysis}

The global research output in the field of $N$. sativa consisted of 3718 cumulated publications in 30 years during 1989-2018. The $N$. sativa annual research output increased from 6 in the year 1989 to 286 publications in the year 2018, registering $20.87 \%$ growth per annum. The global cumulative output in $N$. sativa research in 15 years (1989-2003) increased from 394 to 3324 publications during the succeeding 15 -year period (2004-2018), registering 743.65\% growth. The citation impact of global publications on $N$. sativa in 30 years averaged to 19.08 citations per publication (CPPs) during 1989-2018; 15-yearly impact averaged to 47.19 CPP for the period 1989-2003, which sharply declined to 15.75 CPP in the succeeding 15 years (2004-2018) [Table 1]. Of the total global publications, $87.41 \%$ (3250) appeared as articles, $7.88 \%$ (293) as reviews, $1.53 \%(57)$ as conference papers, and the rest have below 1\% share: articles in
Table 1: Annual and cumulative publication world output in Nigella sativa research, 1989-2018

\begin{tabular}{|c|c|c|c|}
\hline \multirow{2}{*}{ Publication period } & \multicolumn{3}{|c|}{ World } \\
\hline & TP & $\mathrm{TC}$ & CPP \\
\hline 1989 & 6 & 83 & 13.83 \\
\hline 1990 & 13 & 297 & 22.85 \\
\hline 1991 & 7 & 686 & 98.00 \\
\hline 1992 & 15 & 488 & 32.53 \\
\hline 1993 & 20 & 1008 & 50.40 \\
\hline 1994 & 9 & 123 & 13.67 \\
\hline 1995 & 17 & 1504 & 88.47 \\
\hline 1996 & 18 & 312 & 17.33 \\
\hline 1997 & 26 & 603 & 23.19 \\
\hline 1998 & 22 & 897 & 40.77 \\
\hline 1999 & 28 & 1309 & 46.75 \\
\hline 2000 & 30 & 2674 & 89.13 \\
\hline 2001 & 33 & 1535 & 46.52 \\
\hline 2002 & 55 & 2812 & 51.13 \\
\hline 2003 & 95 & 4262 & 44.86 \\
\hline 2004 & 83 & 3092 & 37.25 \\
\hline 2005 & 114 & 4879 & 42.80 \\
\hline 2006 & 113 & 3965 & 35.09 \\
\hline 2007 & 144 & 4321 & 30.01 \\
\hline 2008 & 166 & 7935 & 47.80 \\
\hline 2009 & 161 & 3355 & 20.84 \\
\hline 2010 & 216 & 5330 & 24.68 \\
\hline 2011 & 270 & 4501 & 16.67 \\
\hline 2012 & 249 & 3720 & 14.94 \\
\hline 2013 & 276 & 3524 & 12.77 \\
\hline 2014 & 325 & 3110 & 9.57 \\
\hline 2015 & 273 & 2119 & 7.76 \\
\hline 2016 & 317 & 1598 & 5.04 \\
\hline 2017 & 331 & 734 & 2.22 \\
\hline 2018 & 286 & 167 & 0.58 \\
\hline 1989-2003 & 394 & 18,593 & 47.19 \\
\hline 2004-2018 & 3324 & 52,350 & 15.75 \\
\hline 1989-2018 & 3718 & 70,943 & 19.08 \\
\hline
\end{tabular}

TP: Total paper, TC: Total citation, CPP: Citations per paper

press $(0.70 \%)$, book chapters $(0.62 \%)$, notes $(0.56 \%)$, letters $(0.51 \%)$, erratum $(0.35 \%)$, editorials $(0.22 \%)$, short surveys $(0.19 \%)$, and book $(0.03 \%)$.

Top ten most productive countries in Nigella sativa research

102 countries participated in global research in N. sativa research during 1989-2018, of which, 47 published 1-10 papers each, 37 countries $11-50$ papers each, 6 countries 51-100 papers each, 11 countries 101-400 papers each, and 1 country 889 papers. The top ten most productive countries in $N$. sativa research contributed 117-889 publications each during 1989-2018. The top ten most productive countries in $N$. sativa research accounted for $81.31 \%$ global publication share and $75.64 \%$ citation share during 1989-2018. Their 15-yearly output accounted for $70.56 \%$ global publication share during 1989-2003 which increased to $82.58 \%$ during the succeeding 15-year period (2004-2018). Country wise, the global publication share of the top ten countries varied widely from $3.15 \%$ to $23.91 \%$ during $1989-2018$, with India accounting for the highest publication share (23.91\%), 
followed by Iran $(9.58 \%)$, Egypt $(9.06 \%)$, the USA and Saudi Arabia (7.15\% and 7.07\%), Turkey (6.62\%), Pakistan (5.7\%), Malaysia, China, and Germany (from $3.15 \%$ to $4.92 \%$ ) during 1989-2018 [Table 2].

The global publication share registered an increasing publication share varying from $0.35 \%$ to $8.16 \%$ in seven countries namely Iran, Malaysia, China, Pakistan, India, Turkey, and Egypt, as against decrease from 1.17\% to 5.28\% in three countries, namely Saudi Arabia, the USA, and Germany in 15-year period (1989-2003 and 2004-2018). Five of the top ten countries scored relative citation index above the world average of 0.93: Germany (1.86), the USA (1.54), Turkey (1.33), Saudi Arabia (1.16), and Egypt (0.94) during 1989-2018. India has though emerged as one of the world leaders in research productivity of $N$. sativa research, its performance in terms of relative citation index $(0.68)$ has been below the world average.

\section{International collaboration}

The international collaborative output of the top ten most productive countries in $N$. sativa research as a national share in the country-wise output varied widely from $11.24 \%$ to $53.61 \%$, with average share of $28.02 \%$ during $1989-2018$. The highest international collaborative publication share comes from Saudi Arabia (53.61\%), followed by Germany $(50.43 \%)$, Malaysia (48.63\%), the USA (48.50\%), Egypt (42.14\%), China (33.77\%), Pakistan (28.77\%), Turkey (13.41\%), India (11.36\%), and Iran (11.24\%) during 1989-2018. Most surprisingly, India's international collaborative share in its national output in $N$. sativa research has been comparatively small and one of the lowest, $11.36 \%$.

\section{Subject-wise distribution of research output}

$N$. sativa, as a medicinal and nutritional plant, became the focus of interest among researchers from biological sciences, medical sciences, chemistry, agriculture, and veterinary sciences during the early 1970s. Here, the global N. sativa research output published during 1989-2018 is distributed across eight subfields (as identified in Scopus database classification), with pharmacology, toxicology, and pharmaceutics accounting for the highest publications share $(33.97 \%)$, followed by agricultural and biological sciences $(32.92 \%)$, medicine $(30.10 \%)$, biochemistry, genetics, and molecular biology $(24.74 \%)$, chemistry $(12.40 \%)$, immunology and microbiology (6.97\%), environmental science $(5.38 \%)$, and veterinary science $(3.60 \%)$ during 1989-2018. Its activity index, which computes change in research activity in the discipline over time 1989-2003 to 2004-2018 (World Average Activity index of a given subject is taken as 100), witnessed increase in immunology and microbiology (from 61.94 to 104.51), veterinary science (from 63.48 to 104.34), medicine (from 76.74 to 102.76), and environmental science (from 94.37 to 100.67), as against decrease in chemistry (from 145.34 to 94.63), pharmacology, toxicology, and pharmaceutics (from 112.82 to 98.48$)$, biochemistry, genetics, and molecular biology (from 106.67 to 99.21), and agricultural and biological sciences (from 103.31 to 99.61).

Chemistry, among various subjects, registered the highest citation impact per paper of 25.08 CPP, followed by pharmacology, toxicology, and pharmaceutics (24.85), biochemistry, genetics, and molecular biology (21.23), immunology and microbiology (21.06), medicine (19.65), agricultural and biological sciences (18.44), veterinary science (17.78), and environmental science (13.60) during 1989-2018 [Table 3].

Profile of the top 15 most productive global organizations Four hundred and thirty-two organizations participated in the global research on N. sativa during 1989-2018, of

\begin{tabular}{|c|c|c|c|c|c|c|c|c|c|c|c|c|}
\hline \multirow{2}{*}{$\begin{array}{l}\text { Serial } \\
\text { number }\end{array}$} & \multirow{2}{*}{$\begin{array}{l}\text { Name of the } \\
\text { country }\end{array}$} & \multicolumn{3}{|c|}{ Number of papers } & \multicolumn{3}{|c|}{ Share of papers } & \multirow[t]{2}{*}{ TC } & \multirow[t]{2}{*}{ CPP } & \multirow{2}{*}{\multicolumn{2}{|c|}{$\begin{array}{l}\text { ICP Percentage } \\
\text { ICP }\end{array}$}} & \multirow[t]{2}{*}{$\mathrm{RCl}$} \\
\hline & & $1989-2003$ & 2004-2018 & $1989-2018$ & $1989-2003$ & $2004-2018$ & $1989-2018$ & & & & & \\
\hline 1 & India & 84 & 805 & 889 & 21.32 & 24.22 & 23.91 & 11,538 & 12.98 & 101 & 11.36 & 0.68 \\
\hline 2 & Iran & 9 & 347 & 356 & 2.28 & 10.44 & 9.58 & 5102 & 14.33 & 40 & 11.24 & 0.75 \\
\hline 3 & Egypt & 35 & 302 & 337 & 8.88 & 9.09 & 9.06 & 6050 & 17.95 & 142 & 42.14 & 0.94 \\
\hline 4 & USA & 44 & 222 & 266 & 11.17 & 6.68 & 7.15 & 7834 & 29.45 & 129 & 48.50 & 1.54 \\
\hline 5 & Saudi Arabia & 32 & 231 & 263 & 8.12 & 6.95 & 7.07 & 5818 & 22.12 & 141 & 53.61 & 1.16 \\
\hline 6 & Turkey & 25 & 221 & 246 & 6.35 & 6.65 & 6.62 & 5707 & 23.20 & 33 & 13.41 & 1.22 \\
\hline 7 & Pakistan & 12 & 200 & 212 & 3.05 & 6.02 & 5.70 & 3125 & 14.74 & 61 & 28.77 & 0.77 \\
\hline 8 & Malaysia & 4 & 179 & 183 & 1.02 & 5.39 & 4.92 & 1841 & 10.06 & 89 & 48.63 & 0.53 \\
\hline 9 & China & 2 & 152 & 154 & 0.51 & 4.57 & 4.14 & 2492 & 16.18 & 52 & 33.77 & 0.85 \\
\hline 10 & Germany & 31 & 86 & 117 & 7.87 & 2.59 & 3.15 & 4157 & 35.53 & 59 & 50.43 & 1.86 \\
\hline Total & & 278 & 2745 & 3023 & 70.56 & 82.58 & 81.31 & 53,664 & 17.75 & 847 & 28.02 & 0.93 \\
\hline \multirow{2}{*}{\multicolumn{2}{|c|}{ World output }} & 394 & 3324 & 3718 & & & & 70,943 & 19.08 & & & \\
\hline & & 70.56 & 82.58 & 81.31 & & & & 75.64 & & & & \\
\hline
\end{tabular}
in world total

TC: Total citation, CPP: Citations per paper, ICP: International collaborative paper, RCI: Relative citation index 
which 344 organizations contributed $1-10$ papers each, 64 organizations 11-20 papers each, 18 organizations $21-50$ papers each, 5 organizations 51-100 papers each, and 1 organization 116 papers.

The productivity of the top 15 most productive global organizations in $N$. sativa research varied from 33 to 116 publications and together they contributed $23.45 \%$ (872) publication share and $21.82 \%$ (15477) citation share during 1989-2018. The scientometric profile of these top 15 organizations is presented in Table 4.

- Five organizations registered publication output greater than the group average of 58.13: Marshad University of Medical Sciences, Iran (116 papers), Indian Institute of Spice Research, India (93 papers), King Saud University, Saudi Arabia (93 papers), National Research Centre, Egypt (82 papers), and Universiti Putra, Malaysia (81 papers)

- Five organizations registered impact and relative citation index above the group average of 17.75 citations per publication and 0.93 during 1989-2018: King Saud
University, Saudi Arabia (37.54 and 1.97), Imam Abdulrahman Bin Faisal University, Saudi Arabia (28.24 and 1.48), University of Karachi, Pakistan (25.40 and 1.30), Cairo University, Egypt (24.85 and 1.30), and Marshad University of Medical Sciences, Iran (18.73 and 0.98 )

- Nine organizations contributed international collaborative publications share above the group average of 30.62\%: King Abdulaziz University, Saudi Arabia (68.52\%), Zagazig University, Egypt (64.10\%), Universiti Putra, Malaysia (58.02\%), Alexandria University, Egypt (55.56\%), King Saud University, Saudi Arabia (44.09\%), Cairo University, Egypt (41.46\%), University of Karachi, Pakistan (35.71\%), Ain Shams University, Egypt (33.33\%), and University of Agriculture, Faisalabad, Pakistan (31.11\%).

Profile of the top 25 most productive authors

Six hundred and forty-two authors participated in the global research on N. sativa during 1989-2018, of which

Table 3: Subject-wise breakup of global publications in Nigella sativa research during 1989-2018

\begin{tabular}{|c|c|c|c|c|c|c|c|c|c|}
\hline \multirow[t]{2}{*}{ Serial number } & \multirow[t]{2}{*}{ Subject* } & \multicolumn{3}{|c|}{ Number of papers (TP) } & \multicolumn{2}{|c|}{ Activity index } & \multirow[t]{2}{*}{ TC } & \multirow{2}{*}{\multicolumn{2}{|c|}{$\begin{array}{l}\text { CPP Percentage TP } \\
1989-2018 \\
\end{array}$}} \\
\hline & & 1989-2003 & 2004-2018 & $1989-2018$ & 1989-2003 & $2004-2018$ & & & \\
\hline 1 & $\begin{array}{l}\text { Pharmacology, toxicology } \\
\text { and pharmaceutics }\end{array}$ & 151 & 1112 & 1263 & 112.82 & 98.48 & 31387 & 24.85 & 33.97 \\
\hline 2 & $\begin{array}{l}\text { Agricultural and biological } \\
\text { sciences }\end{array}$ & 134 & 1090 & 1224 & 103.31 & 99.61 & 22570 & 18.44 & 32.92 \\
\hline 3 & Medicine & 91 & 1028 & 1119 & 76.74 & 102.76 & 21987 & 19.65 & 30.10 \\
\hline 4 & $\begin{array}{l}\text { Biochemistry, genetics and } \\
\text { molecular biology }\end{array}$ & 104 & 816 & 920 & 106.67 & 99.21 & 19536 & 21.23 & 24.74 \\
\hline 5 & Chemistry & 71 & 390 & 461 & 145.34 & 94.63 & 11561 & 25.08 & 12.40 \\
\hline 6 & $\begin{array}{l}\text { Immunology and } \\
\text { microbiology }\end{array}$ & 17 & 242 & 259 & 61.94 & 104.51 & 5454 & 21.06 & 6.97 \\
\hline 7 & Environmental science & 20 & 180 & 200 & 94.37 & 100.67 & 2719 & 13.60 & 5.38 \\
\hline $\begin{array}{l}8 \\
\text { World output }\end{array}$ & Veterinary science & $\begin{array}{c}9 \\
394\end{array}$ & $\begin{array}{c}125 \\
3324\end{array}$ & $\begin{array}{c}134 \\
3718\end{array}$ & 63.38 & 104.34 & 2382 & 17.78 & 3.60 \\
\hline
\end{tabular}

There is overlapping of literature covered under various subjects. TP: Total paper, TC: Total citation, CPP: Citations per paper

Table 4: Scientometric profile of top 15 most productive global organizations in Nigella sativa research during 1989-2018

\begin{tabular}{|c|c|c|c|c|c|c|c|c|}
\hline Serial number & Name of the organization & TP & $\mathrm{TC}$ & $\mathrm{CPP}$ & $\mathrm{HI}$ & $\mathrm{ICP}$ & Percentage ICP & $\mathrm{RCl}$ \\
\hline 1 & Marshad University of Medical Sciences, Iran & 116 & 2173 & 18.73 & 27 & 5 & 4.31 & 0.98 \\
\hline 2 & Indian Institute of Spice Research, India & 93 & 713 & 7.67 & 16 & 4 & 4.30 & 0.40 \\
\hline 3 & King Saud University, Saudi Arabia & 93 & 3491 & 37.54 & 29 & 41 & 44.09 & 1.97 \\
\hline 4 & National Research Centre, Egypt & 82 & 1036 & 12.63 & 18 & 18 & 21.95 & 0.66 \\
\hline 5 & Universiti Putra, Malaysia & 81 & 1112 & 13.73 & 20 & 47 & 58.02 & 0.72 \\
\hline 6 & King Abdulaziz University, Saudi Arabia & 54 & 648 & 12.00 & 12 & 37 & 68.52 & 0.63 \\
\hline 7 & Aligarh Muslim University, India & 46 & 673 & 14.63 & 14 & 7 & 15.22 & 0.77 \\
\hline 8 & University of Agriculture, Faisalabad, Pakistan & 45 & 761 & 16.91 & 15 & 14 & 31.11 & 0.89 \\
\hline 9 & University of Karachi, Pakistan & 42 & 1067 & 25.40 & 18 & 15 & 35.71 & 1.33 \\
\hline 10 & Cairo University, Egypt & 41 & 1019 & 24.85 & 11 & 17 & 41.46 & 1.30 \\
\hline 11 & Zagazig University, Egypt & 39 & 540 & 13.85 & 11 & 25 & 64.10 & 0.73 \\
\hline 12 & Ain Shams University, Egypt & 36 & 350 & 9.72 & 10 & 12 & 33.33 & 0.51 \\
\hline 13 & Alexandria University, Egypt & 36 & 489 & 13.58 & 11 & 20 & 55.56 & 0.71 \\
\hline 14 & Tehran University of Medical Sciences, Iran & 35 & 473 & 13.51 & 9 & 3 & 8.57 & 0.71 \\
\hline 15 & Imam Abdulrahman Bin Faisal University, Saudi Arabia & 33 & 932 & 28.24 & 13 & 2 & 6.06 & 1.48 \\
\hline \multicolumn{2}{|c|}{ Total of 15 organizations } & 872 & 15,477 & 17.75 & 15.6 & 267 & 30.62 & 0.93 \\
\hline \multicolumn{2}{|c|}{ Total of world } & 3718 & 70,943 & 19.08 & & & & \\
\hline \multicolumn{2}{|c|}{ Share of top 15 organizations in world output } & 23.45 & 21.82 & & & & & \\
\hline
\end{tabular}

TP: Total paper, TC: Total citation, CPP: Citations per paper, HI: h-index, ICP: International collaborative paper, RCI: Relative citation index 
499 authors contributed $1-5$ papers each, 100 authors $6-10$ papers each, 40 authors $11-20$ papers each, and 3 authors 21-29 papers each.

The research productivity in the field of $N$. sativa research of the top 15 most productive authors varied from 12 to 29 publications. Together, they contributed 6.64\% (247) global publication share and 8.04\% (5707) citation share during 1989-2018. The scientometric profile of these 15 authors is presented in Table 5.

- Five authors registered publications output above the group average of 16.47: H. Hosseinzadeh (29 papers), M. H. Boskabady (24 papers), M. Kanter (21 papers), M. F. Ramadan (20 papers), and A. I. Bhat (18 papers)

- Six authors registered impact and relative citation index above the group average of 19.08 citations per publication and 1.31: K. G. M. Kanter (56.29 and 2.95), A. H. Gilani (31.46 and 1.65), M. H. Boskabady (27.63 and 1.45), H. Hosseinzadeh (27.03 and 1.42), M. T. Sultan (24.92 and 1.31), and A. O. Bamosa (21.14 and 1.11)

- Five authors contributed international collaborative publications share above the group average of $14.57 \%$ of all authors: M. F. Ramadan $(60.0 \%)$, A. H. Gilani (46.15\%), M. S. Butt (43.75\%), M. T. Sultan (41.67\%), and A. E. Edris (6.67\%).

\section{Medium of research communication}

Of the total world output on $N$. sativa research, $98.31 \%$ (3655) appeared in journals during 1989-2018. A total of 3655 journal papers appeared in 364 journals, of which 230 journals published $1-5$ papers each, 81 journals 6-10 papers each, 38 journals 11-20 papers each, 13 journals $21-50$ papers each, and 2 journals $51-89$ papers each during 1989-2018.
The top 15 most productive journals reported 21-89 papers each on $N$. sativa research; together, they accounted for $13.54 \%$ (495 papers) share of total $N$. sativa output published in journals during 1989-2018. The top-ranking journal is Journal of Ethnopharmacology (with 89 papers), followed by Phytotherapy Research (54 papers), Food Chemistry and International Journal of Pharmacy and Pharmaceutical Sciences (41 papers each), Journal of Agricultural and Food Chemistry (36 papers), Pharmaceutical Biology (30 papers), etc., during 1989-2018 [Table 6].

\section{Significant keywords}

Around 88 significant keywords having potential to identify comparative research trends in N. sativa literature research studies including pharmacological properties and medicinal uses were discovered globally on $N$. sativa. These keywords are listed in Table 7 in the decreasing order of the frequency of their occurrence in the literature during 1989-2018.

\section{Highly cited papers}

A total of 126 highly cited papers in N. sativa research were identified each having 100-2971 citations (102 papers each in citation range 100-199, 13 papers each in 200-299 citation range, 4 papers each in 300-399 citation range, and 4 papers 407-2971 citation range each) in 30 years during 1989-2018. A total of 126 papers together cumulated a total of 23,426 citations, averaging 185.92 citations per paper. Of the 126 highly cited papers, 67 resulted from the participation of research organizations in their role as stand-alone (noncollaborating) institutional authors and the remaining 28 from two or more research organizations working in their role as collaborating partners per paper $(20$ national collaborative and 31 international collaborative). Among 126 highly cited papers, the largest participation was seen from India (19 papers), followed by the USA (18

Table 5: Scientometric profile of top 15 most productive authors in Nigella sativa research during 1989-2018

\begin{tabular}{|c|c|c|c|c|c|c|c|c|c|}
\hline Serial number & Name of the author & Affiliation of the author & TP & $\mathrm{TC}$ & $\mathrm{CPP}$ & $\mathrm{HI}$ & ICP & Percentage ICP & $\mathrm{RCI}$ \\
\hline 1 & H. Hosseinzadeh & Marshad University of Medical Sciences, Iran & 29 & 784 & 27.03 & 15 & 0 & 0.00 & 1.42 \\
\hline 2 & M. H. Boskabady & Marshad University of Medical Sciences, Iran & 24 & 663 & 27.63 & 16 & 0 & 0.00 & 1.45 \\
\hline 3 & M. Kanter & Trakya University, Turkey & 21 & 1182 & 56.29 & 16 & 0 & 0.00 & 2.95 \\
\hline 4 & M. F. Ramadan & Technical University of Berlin, Germany & 20 & 862 & & 11 & 12 & 60.00 & 0.00 \\
\hline 5 & A. I. Bhat & Indian Institute of Spice Research, India & 18 & 161 & 8.94 & 8 & 2 & 11.11 & 0.47 \\
\hline 6 & M. S. Butt & University of Agriculture, Faisalabad, Pakistan & 16 & 294 & 18.38 & 9 & 7 & 43.75 & 0.96 \\
\hline 7 & M. Anandaraj & Indian Institute of Spice Research, India & 15 & 75 & 5.00 & 4 & 0 & 0.00 & 0.26 \\
\hline 8 & A.O. Bamosa & King Faisal University, Saudi Arabia & 14 & 296 & 21.14 & 8 & 0 & 0.00 & 1.11 \\
\hline 9 & M. Hosseini & Marshad University of Medical Sciences, Iran & 14 & 130 & 9.29 & 7 & 1 & 7.14 & 0.49 \\
\hline 10 & A.H. Gilani & Aga Khan University Medical College, Karachi & 13 & 409 & 31.46 & 7 & 6 & 46.15 & 1.65 \\
\hline 11 & R. Keyhanmanesh & Tabriz University of Medical Sciences, Iran & 13 & 2381 & 18.31 & 8 & 0 & 0.00 & 0.96 \\
\hline 12 & B. Sasikumar & Indian Institute of Spice Research, India & 13 & 132 & 10.15 & 7 & 1 & 7.69 & 0.53 \\
\hline 13 & S. H. Shah & Aligarh Muslim University, India & 13 & 88 & 6.77 & 6 & 0 & 0.00 & 0.35 \\
\hline 14 & A. E. Edris & National Research Centre, Cairo, Egypt & 12 & 94 & 7.83 & 6 & 2 & 16.67 & 0.41 \\
\hline 15 & M. T. Sultan & University of Agriculture, Faisalabad, Pakistan & 12 & 299 & 24.92 & 9 & 5 & 41.67 & 1.31 \\
\hline \multicolumn{3}{|c|}{ Total of 15 authors } & 247 & 5707 & 273.14 & 9.13 & 36 & 14.57 & \\
\hline \multicolumn{3}{|l|}{ Total of world } & 3718 & 70,943 & 19.08 & & & & \\
\hline \multicolumn{3}{|c|}{ Share of top 15 authors in world total output } & 6.64 & 8.04 & & & & & \\
\hline
\end{tabular}

TP: Total paper, TC: Total citation, CPP: Citations per paper, HI: h-index, ICP: International collaborative paper, RCI: Relative citation index 
Table 6: Top 15 most productive journals in Nigella sativa research during 1989-2018

\begin{tabular}{|c|c|c|}
\hline Serial number & Name of the journal & Number of papers \\
\hline 1 & Journal of Ethnopharmacology & 89 \\
\hline 2 & Phytotherapy Research & 54 \\
\hline 3 & Food Chemistry & 41 \\
\hline 4 & $\begin{array}{l}\text { International Journal of } \\
\text { Pharmacy and Pharmaceutical } \\
\text { Sciences }\end{array}$ & 41 \\
\hline 5 & $\begin{array}{l}\text { Journal of Agricultural and Food } \\
\text { Chemistry }\end{array}$ & 36 \\
\hline 6 & Pharmaceutical Biology & 30 \\
\hline 7 & $\begin{array}{l}\text { Pakistan Journal of } \\
\text { Pharmaceutical Sciences }\end{array}$ & 26 \\
\hline 8 & Nature Product Research & 24 \\
\hline 9 & PLOS One & 24 \\
\hline 10 & $\begin{array}{l}\text { Evidence-based } \\
\text { Complementary and Alternate } \\
\text { Medicine }\end{array}$ & 23 \\
\hline 11 & $\begin{array}{l}\text { Asian Journal of Pharmaceutical } \\
\text { and Clinical Research }\end{array}$ & 22 \\
\hline 12 & $\begin{array}{l}\text { BMC Complementary and } \\
\text { Alternate Medicine }\end{array}$ & 22 \\
\hline 13 & Industrial Crops and Products & 21 \\
\hline 14 & Phytomedicine & 21 \\
\hline 15 & Planta Medica & 21 \\
\hline \multicolumn{2}{|c|}{ Total of 15 journals } & 495 \\
\hline \multicolumn{2}{|c|}{ Total global journal output } & 3655 \\
\hline \multicolumn{2}{|c|}{ Share of top 15 journals in global journal output } & 13.54 \\
\hline
\end{tabular}

papers), Egypt (17 papers), Saudi Arabia (13 papers), Turkey (12 papers), Germany (11 papers), Morocco (7 papers), Iran (6 papers), Japan, Singapore, and the UK (5 papers each), China and Thailand (4 papers each), Austria, Australia, Brazil, Libya, Pakistan, and Tunisia (3 papers each), Canada, France, Italy, and South Korea (2 papers each), Cameroon, Bangladesh, Belgium, Hungry, Israel, Jordan, Malaysia, the Netherlands, South Korea, Spain, and Switzerland (1 paper each).

These 126 highly cited papers involved the participation of 492 personal authors and 362 research organizations in total across the globe. Of the 126 highly cited papers, 107 were published as articles, 19 as review papers, and 1 as letter. These 126 highly cited papers were published in 77 journals, with 18 papers in the Journal of Ethnopharmacology, 8 papers in Food Chemistry, 6 papers in Phytotherapy Research, 5 papers in Planta Medica, 4 papers each in the Journal of Agricultural and Food Chemistry and Phytomedicine, 3 papers each in Cancer Letters and International Immunopharmacology, 2 papers each in Food and Chemical Toxicology, BMC Complementary and Alternate Medicine, Parasitology, and World Journal of Gastroenterology, and 1 paper each in other journals.

\section{RESULTS AND CONCLUSION}

Research publications' output on N. sativa, sourced from the Scopus database, were analyzed in this study to provide a quantitative and qualitative description of its global
Table 7: List of significant keywords in literature on Nigella sativa research during 1989-2018

\begin{tabular}{|c|c|c|}
\hline Serial number & Keyword & Frequency \\
\hline 1 & Nigella sativa & 1931 \\
\hline 2 & Black pepper & 1149 \\
\hline 3 & Black cumin & 1014 \\
\hline 4 & Plant extract & 873 \\
\hline 5 & Piper nigrum & 694 \\
\hline 6 & Plant seed & 616 \\
\hline 7 & Medicinal plant & 469 \\
\hline 8 & Chemistry & 468 \\
\hline 9 & Thymoquinone & 437 \\
\hline 10 & Drug effect & 427 \\
\hline 11 & Antioxidant activity & 385 \\
\hline 12 & Essential oils & 327 \\
\hline 13 & Piperine & 293 \\
\hline 14 & Metabolism & 291 \\
\hline 15 & Phytotherapy & 283 \\
\hline 16 & Oxidation stress & 270 \\
\hline 17 & Herbaceous agent & 263 \\
\hline 18 & Drug efficacy & 251 \\
\hline 19 & Antioxidantsz & 244 \\
\hline 20 & Enzyme activity & 234 \\
\hline 21 & Vegetable oils & 229 \\
\hline 22 & Drug mechanism & 226 \\
\hline 23 & Drug effects & 219 \\
\hline 24 & Spice & 213 \\
\hline 25 & Benzoquinones & 210 \\
\hline 26 & Plant oils & 201 \\
\hline 27 & Traditional medicine & 186 \\
\hline 28 & Anti-inflammatory activity & 177 \\
\hline 29 & Pepper & 166 \\
\hline 30 & Anti-bacterial activity & 157 \\
\hline 31 & Drug screening & 157 \\
\hline 32 & Anti-neoplastic activity & 153 \\
\hline 33 & Apoptosis & 153 \\
\hline 34 & Fruit & 152 \\
\hline 35 & Nigella sativa oil & 148 \\
\hline 36 & Phytochemistry & 169 \\
\hline 37 & Lipid peroxidation & 168 \\
\hline 38 & Drug isolation & 145 \\
\hline 39 & Plant leaf & 141 \\
\hline 40 & Herbal medicine & 135 \\
\hline 41 & Superoxide dismutare & 147 \\
\hline 42 & Glucose & 138 \\
\hline 43 & Staphylococcus aureus & 135 \\
\hline 44 & Malonaldehyde & 134 \\
\hline 45 & Escherichia coli & 131 \\
\hline 46 & Piper longum & 131 \\
\hline 47 & Glutathione & 129 \\
\hline 48 & Alkaloids & 128 \\
\hline 49 & Anti-microbial activity & 128 \\
\hline 50 & Alanine aminotransferase & 125 \\
\hline 51 & Diabetes mellitus & 124 \\
\hline 52 & Clove & 121 \\
\hline 53 & Protein expression & 119 \\
\hline 54 & Body weight & 115 \\
\hline 55 & Piperidines & 114 \\
\hline 56 & Glucose blood level & 113 \\
\hline 57 & Catalase & 112 \\
\hline 58 & Drug activity & 111 \\
\hline 59 & Aspartale aminotransferase & 109 \\
\hline 60 & Cholesterol & 109 \\
\hline 61 & Cytoxity & 106 \\
\hline 62 & Benzoquinone derivatives & 105 \\
\hline 63 & Piperaceae & 104 \\
\hline 64 & Polyunsaturated alkamides & 103 \\
\hline
\end{tabular}

Contd... 
Table 7: Contd...

\begin{tabular}{llc}
\hline Serial number & Keyword & Frequency \\
\hline 65 & Benzodioxoles & 102 \\
66 & Drug structure & 99 \\
67 & Genetics & 98 \\
68 & Inflammation & 96 \\
69 & Pathology & 95 \\
70 & Ranunculaceae & 95 \\
71 & Liver & 94 \\
72 & Anti-infective agents & 93 \\
73 & Physiology & 91 \\
74 & Placebo & 90 \\
75 & Diet supplement & 89 \\
76 & Amide & 88 \\
77 & Bacteria & 88 \\
78 & Liver protection & 87 \\
79 & Drug safety & 86 \\
80 & Drug formulation & 82 \\
81 & Volatile oils & 82 \\
82 & DPPH radical scavenging assay & 38 \\
83 & Bacterium & 37 \\
84 & Bacillus cereus & 32 \\
85 & Gamma interferon & 28 \\
86 & Glutamyltranserase & 22 \\
87 & DNA & 20 \\
88 & Sclipta prostate & 20 \\
89 & Fatty lever & 19 \\
\hline
\end{tabular}

research output covering 30-year period (1989-2018). The study showed that annual and 15-year cumulative global output of N. sativa registered $20.87 \%$ and $743.65 \%$ growth. Its global citation impact averaged to 19.08 citations per paper during 1989-2018, which declined from 47.19 during 1989-2003 to 15.75 during 2004-2018.

One hundred and two countries participated in global research in $N$. sativa research during 1989-2018, of which the top ten most productive countries together accounted for $81.31 \%$ global publication share and $75.64 \%$ citation share. Their 15-yearly output accounted for $70.56 \%$ global publication share during 1989-2003 which increased to $82.58 \%$ during the succeeding 15 -year period (2004-2018).

India took the lead and accounted for the highest publication share $(23.91 \%)$, followed by Iran $(9.58 \%)$, Egypt $(9.06 \%)$, the USA and Saudi Arabia $(7.15 \%$ and $7.07 \%)$, Turkey (6.62\%), Pakistan (5.7\%), and Malaysia, China, and Germany (from 3.15\% to $4.92 \%$ ) during 1989-2018. Iran, Malaysia, China, Pakistan, India, Turkey, and Egypt registered increasing global publication share varying from $0.35 \%$ to $8.16 \%$, as against decrease from $1.17 \%$ to $5.28 \%$ in three countries, namely Saudi Arabia, the USA, and Germany from 1989-2003 to 2004-2018. Five countries scored relative citation index above the world average of 0.93: Germany (1.86), the USA (1.54), Turkey (1.33), Saudi Arabia (1.16), and Egypt (0.94) during 1989-2018.
Pharmacology, toxicology, and pharmaceutics were the most sought-after subject areas of $N$. sativa research accounting for the highest publications share (33.97\%), followed by agricultural and biological sciences (32.92\%), medicine $(30.10 \%)$, biochemistry, genetics, and molecular biology $(24.74 \%)$, chemistry $(12.40 \%)$, immunology and microbiology (6.97\%), environmental science (5.38\%), and veterinary science $(3.60 \%)$ during $1989-2018$. The research activities showed increase in immunology and microbiology, veterinary science, medicine, and environmental science, as against decrease in chemistry, pharmacology, toxicology and pharmaceutics, biochemistry, genetics and molecular biology, and agricultural and biological sciences from 1989-2003 to 2004-2018.

A total of 432 organizations and 642 authors participated in global research on N. sativa during 1989-2018, of which the top 15 most productive research organizations and the authors collectively contributed $23.45 \%$ and $6.64 \%$ global publication share and $21.82 \%$ and $8.04 \%$ global citation share, respectively, during 1989-2018.

The leading organizations in terms of publication productivity were: Marshad University of Medical Sciences, Iran (116 papers), Indian Institute of Spice Research, India (93 papers), King Saud University, Saudi Arabia (93 papers), National Research Centre, Egypt (82 papers), and Universiti Putra, Malaysia (81 papers). The leading organizations in terms of citation impact per paper and relative citation index were: King Saud University, Saudi Arabia (37.54 and 1.97), Imam Abdulrahman Bin Faisal University, Saudi Arabia (28.24 and 1.48), University of Karachi, Pakistan (25.40 and 1.30), Cairo University, Egypt (24.85 and 1.30), and Marshad University of Medical Sciences, Iran (18.73 and 0.98).

The leading authors in terms of publication productivity were: H. Hosseinzadeh (29 papers), M. H. Boskabady (24 papers), M. Kanter (21 papers), M. F. Ramadan (20 papers), and A. I. Bhat (18 papers). The leading authors in terms of citation impact per paper and relative citation index were: K. G. M. Kanter (56.29 and 2.95), A. H. Gilani (31.46 and 1.65), M. H. Boskabady (27.63 and 1.45), H. Hosseinzadeh (27.03 and 1.42), M. T. Sultan (24.92 and 1.31), and A. O. Bamosa (21.14 and 1.11).

The journals' medium accounted for $98.13 \%$ global share in N. sativa research, with the top 15 most productive journals accounting for $13.54 \%$ of the total publications output in journals during 1989-2018. The Journal of Ethnopharmacology contributed the largest number of papers (89), followed by Phytotherapy Research (54 papers), Food Chemistry and 
International Journal of Pharmacy and Pharmaceutical Sciences (41 papers each), Journal of Agricultural and Food Chemistry (36 papers), Pharmaceutical Biology (30 papers), etc., during 1989-2018.

Of the total N. sativa global research output, 126 publications registered high citations, in the range of 100-2971 citations per paper, and collectively these highly cited papers received a total of 23,426 citations, averaging to 185.92 citations per paper. India's participation was the highest (19 papers) in highly cited papers, followed by the USA (18 papers), Egypt (17 papers), Saudi Arabia (13 papers), Turkey (12 papers), Germany (11 papers), Morocco (7 papers), Iran (6 papers), etc.

These 126 highly cited papers involved the participation of 492 personal authors and 362 research organizations in total across the globe and were published in 77 journals. The leading journals were Journal of Ethnopharmacology (18 papers), followed by Food Chemistry (8 papers), Pbytotherapy Research (6 papers), Planta Medica (5 papers), Journal of Agricultural and Food Chemistry and Phytomedicine (4 papers each), etc.

It was noticed that, although India leads in research output among the top ten countries, it had registered low citation impact per paper (12.68) and low relative citation index (0.68) compared to other leading countries. It is, therefore, suggested that India in particular needs to give higher priority to plant-based research and needs to coordinate, monitor, and prioritize their $\mathrm{R}$ and $\mathrm{D}$ efforts, with higher financial and workforce investment in $\mathrm{R}$ and $\mathrm{D}$ and increase their international collaboration, with a view to increase their research output and improved research impact.

In the last few years, ethno-botanical and traditional uses of natural compounds, especially of plant origin, received serious attention as they are well tested for their efficacy and generally believed to be safe for humanities. They obviously deserve scrutiny on modern scientific lines such as phytochemical investigation, biological evaluation on experimental animal models, toxicity studies, and investigation of molecular mechanism of actions of isolated phytoconstituents. N. sativa is reported to possess antitumor, antidiabetic, cardiovascular, pulmonary, gastroprotective, antifertility, diuretic, central nervous system depressant, antispasmolytic, anti-inflammatory, antimicrobial, antioxidant, anticonvulsants, antinociceptive, anti-urolithatic, anxiolytic, neophroprotective, heptoprotective, immunomodulatory, and anthelmintic activities, but a number of other pharmacological activities are yet to be explored. In future studies, it is suggested that isolated principles from seeds need to be evaluated in a scientific manner using specific experimental animal models, and clinical trials need to be undertaken to understand the molecular mechanism of action in search of lead molecules from natural resources.

\section{Financial support and sponsorship}

Nil.

\section{Conflicts of interest}

There are no conflicts of interest.

\section{REFERENCES}

1. Paarakh P. Nigella sativa Linn - A comprehensive review. Indian J Nat Prod Resour 2010;1:409-29.

2. Ahmad A, Husain A, Mujeeb M, Khan SA, Najmi AK, Siddique NA, et al. A review on therapeutic potential of Nigella sativa: A miracle herb. Asian Pac J Trop Biomed 2013;3:337-52.

3. Ali BH, Blunden G. Pharmacological and toxicological properties of Nigella sativa. Phytother Res 2003;17:299-305.

4. Salem ML. Immunomodulatory and therapeutic properties of the Nigella sativa L. Seed. Int Immunopharmacol 2005;5:1749-70.

5. Anwar MA. Nigella sativa: A bibliometric study of the literature on Habbat Al-Barakah. Malays J Libr Inf Sci 2005;19:1-18.

6. Gupta BM, Mueen AK, Dhawan SM, Gupta RG. Aloe vera (medicinal plant) Research: A scientometric assessment of global publications output during 2007-16. Pharmacogn J 2018;10:1-8.

7. Gupta BM, Mueen Ahmed KK. Research on Azadirachta indica: A scientometric assessment of global publications output during 1997-2016. Pharmacogn J 2019;11:164-72.

8. Mueen AK, Gupta BM, Gupta R. Curcuma longa (medicinal plant) research: A scientometric assessment of global publications output during 1997-2016. Pharmacogn J 2018;10:998-1006.

9. Gupta BM, Mueen AK, Gupta RG. Glycyrrbiza glabre (medicinal plant) research: A scientometric assessment of global publications output during 1997-2016. Pharmacogn J 2018;10:1067-75.

10. Gupta BM, Gupta R, Agarwal A, Goel S. Ocimum santum (medicinal plant) research: A scientometric assessment of global publications output during 2008-17. Int J Inf Dissem Technol 2018;8:67-73.

11. Ibrahim A, Mueen KK, Gupta BM. Global research output on date palm (Pheonix dactylifera): A 12 year's scientometrics perspective. Scientometrics 2014;98:157-71.

12. Gupta BM, Mueen AK, Gupta RG. Global research on Tinospora cordifolia (medicinal plant) with special reference to India: A scientometric assessment of publications output during 2001-16. Int J Pharmacogn Chin Med 2018;2:1-11.

13. Gupta BM, Dhawan SM, Gupta R. Phyllanthis emblica (Medicinal plant) research: A scientometric assessment of global publications output during 2008-17. EC Pharmacol Toxicol 2019;7:18-28. 